Aim of the study: In breast cancer, oestrogen receptor (ER), progesterone receptor (PgR), and HER2 (HER2/Neu) expression status are used to classify neoplasms into subtypes: Luminal $A$ Luminal B, HER2/Neu type, and Basallike. The aim of the present study was to establish the molecular subtypes of breast cancers and their association with tumour characteristics and reproductive factors in Mexican women.

Material and methods: A total of 1326 biopsies of breast tumour tissues were analysed for $E R, P R$, and HER2/Neu by immunohistochemistry (IHC). Information regarding age, tumour characteristics, and node involvement profiles were collected. Results: IHC established that the most common subtype of breast cancer was Luminal A (64.93\%), followed by Basal-Like (13.88\%), Luminal B (12.52\%), and HER2/Neu (8.67\%). T2-size tumours ( $>2 \mathrm{~cm}$ but $<5 \mathrm{~cm}$ ) were present in $47.59 \%$ of all patients. Univariate analysis showed that lymph node positivity $(p=0.009)$, stage $(p=0.013)$, and placement of the tumour $(p=$ $=0.001$ ) were factors associated with breast cancer subtype.

Conclusions: Our data show that $\mathrm{IHC}$ is useful for distinguishing different subtypes of breast cancer and that Luminal $\mathrm{A}$ is the most common breast cancer subtype in the Mexican population. All subtypes were associated with unfavourable clinicopathological features, suggesting that late diagnosis is an important contributor to high mortality rates in the Mexican population.

Key words: breast cancer, immunohis tochemistry, estrogen receptor, progesterone receptor, HER2.

Contemp Oncol (Pozn) 2015; 19 (6): 462-466 DOI: $10.5114 /$ wo.2015.56652

\section{The association of subtypes of breast cancer with tumour characteristics and reproductive factors in 1326 Mexican women}

\author{
Gabriel Pérez-Rodríguez ${ }^{1}$, Catalina Aranda-Moreno ${ }^{1}$, \\ Ivonne M. Olivares-Corichi², Jose R. Garcia-Sanchez ${ }^{2}$
}

${ }^{1}$ Hospital General Regional No. 72 IMSS. Estado de México, México

2Escuela Superior de Medicina del Instituto Politécnico Nacional, México

\section{Introduction}

Breast cancer (BC) is the main cause of death in women worldwide. In Mexico, $B C$ is the primary cause of deaths related to neoplasia in women [1]. $\mathrm{BC}$ represents a group of tumours that display biological behaviour complicated by diverse clinical variability. Histological classification is an important criterion used to determine a prognosis and the most effective treatment for the patient [2-5]. For example, chemotherapy is commonly used for patients with high Ki-67 values, while endocrine therapy is used for ER+ tumours, and anti-HER2 (trastuzumab) therapy is used for HER2 (+) tumours [6]. Furthermore, decisions regarding the use of post-operative adjuvant treatment in recurrent cases are generally based on the ER and HER2 status of the primary tumour and the disease-free interval, recurrence site, and the performance status of the patient [7]. Currently, immunohistochemistry (IHC) is used to classify breast cancer based on the presence or absence of expression of oestrogen receptors (ER+ and ER-). Two subtypes of ER+ tumours have been identified: luminal A (ER+ and/or PgR(+/-), Her2-) and luminal B (ER+, PgR(+/-), Her2+), in addition to two subtypes of ER- tumours: HER2/ Neu (ER-, PgR-, Her2+), and Basal-like (ER-, PgR-, Her2-). While other classifications based on gene expression profiling have also been used to classify breast cancer, the use of this technology in hospitals is currently limited, and assessments are made difficult by the use of paraffin samples [8-11].

In Mexico, most health centres routinely use these biomarkers (ER, PR, and HER2) and IHC to make clinical determinations. However, there are few reports documenting which breast cancer subtypes are detected by each of these biomarkers [12,13]. In the present study, we estimated the prevalence of these biomarkers in breast cancer subtypes and identified associations between reproductive factors and risk for particular subtypes of breast cancer.

\section{Material and methods}

Study population

Tlalnepantla de Baz is located in the north of the state of Mexico; its population is about 664,225 ( $85 \%$ urban and $15 \%$ rural). Cancer cases are diagnosed in different hospitals, clinics, and pathology labs throughout of the state of Mexico, and represent only $60 \%$ of the population. Regional incidence in 2013 was 8.2 per 100,000 women of 25 years old or more.

\section{Patients}

The protocol was approved by the Human Ethics and Research Committee at Hospital Regional No. 72 of the Mexican Institute for Social Security. All patients involved in the study signed an informed consent waiver. The 
study was conducted in accordance with the ethical principles described in the Declaration of Helsinki of 1975, as revised in 1983. The study was also consistent with Good Clinical Practice Guidelines. We assayed 1326 patients who were diagnosed with breast cancer from January 2007 to December 2011 at Hospital Regional No. 72 in the Mexican Institute for Social Security. Clinical information was retrieved from patient medical records, and slides containing biopsies of breast tumour tissues were used to analyse the selected receptors by $\mathrm{IHC}$.

\section{Immunohistochemistry}

Biopsies of breast tumour tissues were obtained, fixed in formalin overnight, and embedded in paraffin. Heat-induced epitope retrieval was performed with sections treated with $0.1 \mathrm{M}$ sodium citrate at $\mathrm{pH}=6.2$ (for PR and HER2) or EDTA buffer at $\mathrm{pH}=9$ (for ER) for 5 minutes in a microwave and incubated for 20 minutes at room temperature. Samples were then treated with hydroxide peroxide (0.3\%) for 5 minutes and with blocking agent (1\% BSA in PBS) for 1 hour prior to incubation with a monoclonal primary antibody against ER (SP1, Lab Vision, Fremont, CA, USA), PgR (PgR636, Lab Vision Fremont, CA, USA) or HER2/neu (A0185, Dako, Carpenteria, CA, USA) overnight at $4^{\circ} \mathrm{C}$. Samples were then treated with Link reagent for 1 hour and streptavidin for another hour (Labelled streptavidin-biotin, Dako Corporation, Carpentería, CA, USA). Finally the slides were treated with diaminobenzidine to visualise ER-, PgR-, or HER2/neu-positive cells. After washing with tap water, sections were counterstained with Mayer's haematoxylin, dehydrated, and mounted.

The four most frequently used classifications were used to analyse IHC results: Luminal A (ER+ and/or PgR(+/-), Her2-), luminal B (ER+, PgR(+/-), Her2+), HER2/Neu: ER-, PgR-, Her2+, and basal-like (ER-, PR-, Her2-). Positive controls were included in each staining run and consisted of breast cancers known to express each of the antigens of interest. Cases were considered positive for ER and PgR when $>5 \%$ and $>10 \%$ of the cells showed expression, respectively. Her2/neu evaluation was performed using the Herceptest ${ }^{\circledR}$ DAKO system, and were scored as follows. Score 0 and 1 = negative: when no immunoreaction occurred or less than $10 \%$ of the cells showed a diffuse immunoreaction. Score $2+=$ positive: a low level of positive signal in the complete membrane in $10 \%$ of the cells. Score $3+=$ positive: overexpression, indicated by strong immunoreactivity in the membrane in more than $10 \%$ of cells. Clinical information was retrieved from patient medical records for risk factors including menopause status, early menarche, late menopause, nulligravida, late pregnancy, and use of hormonal contraceptives. Information regarding other factors was also obtained, including tumour characteristics, the quadrant and side affected, the presence of metastatic axillary nodes, and whether surgery was performed.

\section{Statistical analysis}

All statistical analyses were performed using SPSS version 22. Pearson's $\chi^{2}$ test was used to investigate associa- tions between categorical variables. A $p$-value of less than $0.05(p<0.05)$ was considered statistically significant.

\section{Results}

\section{Patients, clinicopathological features, and breast} cancer subtypes

The study included 1326 patients diagnosed with breast cancer. The clinicopathological features of patients included in the study are shown in Table 1 . Nearly the same percentage of patients were premenopausal as were postmenopausal. Most carcinomas were intermediate stage (70\%), high grade $(21 \%)$, and had a high association with positive nodal status (64\%). Approximately $47.59 \%$ of tumours were between 2 and $5 \mathrm{~cm}$, and 22.1\% were larger (Table 1). Most tumours were ER positive (67.5\%), while a smaller percentage were Her2/neu negative (21\%). Patients were classified according to assessments of positive immunoreactivity for oestrogen receptor, progesterone receptor, and HER2/Neu. Table 2 shows the age at diagnosis and the classification obtained. The IHC study showed that Luminal A (64.93\%) was the most common subtype, followed by Basal-like (13.88\%), Luminal B (12.52\%), and HER2/Neu (8.67\%). The highest percentage of patients were aged $40-69$ years (Table 2 ).

\section{Tumour size in subtypes of breast cancer}

With respect to tumour size, $\mathrm{T} 2$ was the most prevalent $(>2 \mathrm{~cm}$ but $<5 \mathrm{~cm}$ ), with $47 \%$ of all patients scored as $\mathrm{T} 2$.

Table 1. Clinicopathologic features of the study population and immunohistochemical staining results

\begin{tabular}{|c|c|c|}
\hline Clinicopathologic features & No. & $\%$ \\
\hline Total & 1326 & 100 \\
\hline Age (years), mean \pm SD & $53 \pm 11$ & \\
\hline Premenopausal & 692 & 52.2 \\
\hline Postmenopausal & 634 & 47.8 \\
\hline $\begin{array}{l}\text { Stage } \\
\text { I } \\
\text { II } \\
\text { II }\end{array}$ & $\begin{array}{l}119 \\
936 \\
281\end{array}$ & $\begin{array}{c}9 \\
70 \\
21\end{array}$ \\
\hline $\begin{array}{l}\text { Nodal status } \\
\text { negative } \\
\text { positive }\end{array}$ & $\begin{array}{l}477 \\
849\end{array}$ & $\begin{array}{l}36 \\
64\end{array}$ \\
\hline $\begin{array}{l}\text { Tumor size } \\
\text { T1 }(<2 \mathrm{~cm}) \\
\text { T2 }(2-5 \mathrm{~cm}) \\
\text { T3 }(>5 \mathrm{~cm})\end{array}$ & $\begin{array}{l}402 \\
631 \\
293\end{array}$ & $\begin{array}{c}30.32 \\
47.59 \\
22.1\end{array}$ \\
\hline $\begin{array}{l}\text { ER status } \\
\text { positive } \\
\text { negative }\end{array}$ & $\begin{array}{c}1013 \\
313\end{array}$ & $\begin{array}{l}76.4 \\
23.6\end{array}$ \\
\hline $\begin{array}{l}\text { PR status } \\
\text { positive } \\
\text { negative }\end{array}$ & $\begin{array}{l}896 \\
430\end{array}$ & $\begin{array}{l}67.5 \\
32.5\end{array}$ \\
\hline $\begin{array}{l}\text { Her2/neu status } \\
\text { positive } \\
\text { negative }\end{array}$ & $\begin{array}{c}281 \\
1045\end{array}$ & $\begin{array}{l}21 \\
79\end{array}$ \\
\hline
\end{tabular}


Table 2. Tumour subtypes detected in Mexican women and classified by age group

\begin{tabular}{|c|c|c|c|c|c|c|c|c|c|c|}
\hline \multirow[t]{2}{*}{ Age range } & \multicolumn{2}{|c|}{ Luminal A } & \multicolumn{2}{|c|}{ Luminal B } & \multicolumn{2}{|c|}{ HER2/Neu } & \multicolumn{2}{|c|}{ Basal like } & \multicolumn{2}{|c|}{ Total } \\
\hline & $n$ & $\%$ & $n$ & $\%$ & $n$ & $\%$ & $n$ & $\%$ & $n$ & $\%$ \\
\hline $30-39$ & 107 & 8.07 & 14 & 1.06 & 24 & 1.81 & 22 & 1.66 & 167 & 12.59 \\
\hline $40-49$ & 211 & 15.91 & 63 & 4.75 & 32 & 2.41 & 52 & 3.92 & 358 & 27 \\
\hline 50-59 & 279 & 21.04 & 28 & 2.11 & 41 & 3.09 & 64 & 4.83 & 412 & 31.07 \\
\hline $60-69$ & 174 & 13.12 & 43 & 3.24 & 12 & 0.90 & 28 & 2.11 & 257 & 19.38 \\
\hline 70-79 & 64 & 4.83 & 18 & 1.36 & 4 & 0.30 & 18 & 1.36 & 104 & 7.84 \\
\hline $80-89$ & 26 & 1.96 & & & 2 & 0.15 & & & 28 & 2.11 \\
\hline Total & 861 & 64.93 & 166 & 12.52 & 115 & 8.67 & 184 & 13.88 & 1326 & 100 \\
\hline
\end{tabular}

$n$-number of patients, $\%$ - percentage of patients

The Luminal A subtype was observed in the highest percentage of these patients (65\%) (Fig. 1).

Interestingly, in the Basal-like and HER2/Neu subtypes (the two subtypes with highest mortality), $7 \%$ and $4 \%$ of the patients, respectively, had T2 tumours and 3\% of the patients in both subtypes had T3 $(>5 \mathrm{~cm}$ ) tumours (Fig. 1). These data show that in each breast cancer subtype, the majority of patients present unfavourable tumour size characteristics.

Relationship between breast cancer subtype, biological parameters, and reproductive factors

A statistical analysis was performed to explore the relationship between breast cancer subtypes and several factors, including positivity in the axillary lymph node, and the stage, side, and placement of the tumour. As shown in Table $3, \chi^{2}$ analysis revealed a significant association between breast cancer subtype and positivity in the lymph nodes, stage, and placement. In this context, luminal A patients displayed the highest axillary lymph node status, but not Basal like, luminal B, and HER2/Neu patients (39.44\% vs. $9.5 \%, 8.8 \%, 6.18 \%$, respectively). Similar behaviour was observed between these subtypes and stage II (45.78\% vs. $9.43 \%, 9.58 \%, 5.81 \%)(p=0.009)$. These data support the hypothesis that a late detection of this pathology is an important factor that could explain the high mortality in the Mexican population in this disease.

In contrast, there was not a significant association between subtypes and side (Table 3).

Because a large amount of evidence links breast cancer with reproductive factors, different parameters related to these factors were analysed [menopause status, late menopause (age $\geq 54$ years), early menarche (age $\leq 11$ years), late pregnancy (age $\geq 31$ years), and nulligravida]. No significant association was observed between breast cancer subtypes and parameters related to reproductive factors (Table 4). Interestingly, the use of oral contraceptives was the only parameter that showed an association with subtypes of breast cancer (Table 4).

\section{Discussion}

$\mathrm{BC}$ is a major cause of morbidity and mortality in women worldwide. However, evidence indicates that more of $55 \%$ of new cases occur in developing countries [14]. In Mexico,

Table 3. Association of clinical parameters with breast cancer subtype

\begin{tabular}{|c|c|c|c|c|c|c|c|c|c|c|}
\hline & \multicolumn{2}{|c|}{ Luminal A } & \multicolumn{2}{|c|}{ Basal like } & \multicolumn{2}{|c|}{ Luminal B } & \multicolumn{2}{|c|}{ HER2/Neu } & \multirow[t]{2}{*}{ Patients (\%) } & \multirow[t]{2}{*}{${ }^{*} p$ value } \\
\hline & $n$ & $\%$ & $n$ & $\%$ & $n$ & $\%$ & $n$ & $\%$ & & \\
\hline $\begin{array}{l}\text { Lymph node } \\
\text { negative } \\
\text { positive }\end{array}$ & $\begin{array}{l}338 \\
523\end{array}$ & $\begin{array}{l}25.49 \\
39.44\end{array}$ & $\begin{array}{c}57 \\
127\end{array}$ & $\begin{array}{l}4.30 \\
9.58\end{array}$ & $\begin{array}{c}49 \\
117\end{array}$ & $\begin{array}{l}3.70 \\
8.82\end{array}$ & $\begin{array}{l}33 \\
82\end{array}$ & $\begin{array}{l}2.49 \\
6.18\end{array}$ & $\begin{array}{l}477(35.97 \%) \\
849(64.03 \%)\end{array}$ & $0.009^{*}$ \\
\hline $\begin{array}{l}\text { Stage } \\
\text { I } \\
\text { II }\end{array}$ & $\begin{array}{c}88 \\
607 \\
166\end{array}$ & $\begin{array}{c}6.64 \\
45.78 \\
12.52\end{array}$ & $\begin{array}{c}16 \\
125 \\
43\end{array}$ & $\begin{array}{l}1.21 \\
9.43 \\
3.24\end{array}$ & $\begin{array}{c}13 \\
127 \\
36\end{array}$ & $\begin{array}{l}0.98 \\
9.58 \\
2.71\end{array}$ & $\begin{array}{c}2 \\
77 \\
36\end{array}$ & $\begin{array}{l}0.15 \\
5.81 \\
2.71\end{array}$ & $\begin{array}{c}119(8.97 \%) \\
936(70.59 \%) \\
281(21.19 \%)\end{array}$ & $0.010^{*}$ \\
\hline $\begin{array}{l}\text { Side } \\
\text { right } \\
\text { left }\end{array}$ & $\begin{array}{l}479 \\
382\end{array}$ & $\begin{array}{l}36.12 \\
28.81\end{array}$ & $\begin{array}{l}96 \\
88\end{array}$ & $\begin{array}{l}7.24 \\
6.64\end{array}$ & $\begin{array}{l}83 \\
83\end{array}$ & $\begin{array}{l}6.26 \\
6.26\end{array}$ & $\begin{array}{l}61 \\
54\end{array}$ & $\begin{array}{l}4.60 \\
4.07\end{array}$ & $\begin{array}{l}719(54.22 \%) \\
607(45.78 \%)\end{array}$ & 0.521 \\
\hline $\begin{array}{l}\text { Place } \\
\text { UOQ } \\
\text { UIQ } \\
\text { LOQ } \\
\text { CII } \\
\text { central }\end{array}$ & $\begin{array}{r}563 \\
90 \\
18 \\
30 \\
160\end{array}$ & $\begin{array}{c}42.46 \\
6.79 \\
1.36 \\
2.26 \\
12.07\end{array}$ & $\begin{array}{c}144 \\
11 \\
2 \\
8 \\
19\end{array}$ & $\begin{array}{l}10.86 \\
0.83 \\
0.15 \\
0.60 \\
1.43\end{array}$ & $\begin{array}{c}102 \\
20 \\
8 \\
6 \\
30\end{array}$ & $\begin{array}{l}7.69 \\
1.51 \\
0.60 \\
0.45 \\
2.26\end{array}$ & $\begin{array}{c}65 \\
10 \\
8 \\
4 \\
28\end{array}$ & $\begin{array}{l}4.90 \\
0.75 \\
0.60 \\
0.30 \\
2.11\end{array}$ & $\begin{array}{c}874(65.91 \%) \\
131(9.88 \%) \\
36(2.71 \%) \\
48(3.62 \%) \\
237(17.7 \%)\end{array}$ & $0.001^{\star}$ \\
\hline
\end{tabular}

$n$ - number of patients, \% - percentage of patients, UOQ - upper outer quadrant, UIQ - upper inner quadrant, LOQ - lower outer quadrant, LIQ - lower inner quadrant. ${ }^{*} p \leq 0.01$ was considered as statistically significant 
Table 4. Association of hormonal state with breast cancer subtype

\begin{tabular}{|c|c|c|c|c|c|}
\hline & $\begin{array}{l}\text { Luminal A } \\
\text { Patients } \\
861\end{array}$ & $\begin{array}{c}\text { Basal like } \\
\text { Patients } \\
184\end{array}$ & $\begin{array}{l}\text { Luminal B } \\
\text { Patients } \\
166\end{array}$ & $\begin{array}{l}\text { HER2/Neu } \\
\text { Patients } \\
115\end{array}$ & ${ }^{*} p$ value \\
\hline $\begin{array}{l}\text { Menopause status } \\
\text { pre } \\
\text { post }\end{array}$ & $\begin{array}{l}433 \\
428\end{array}$ & $\begin{array}{l}94 \\
90\end{array}$ & $\begin{array}{l}98 \\
68\end{array}$ & $\begin{array}{l}67 \\
48\end{array}$ & 0.104 \\
\hline $\begin{array}{l}\text { Late Menopause } \\
\text { yes } \\
\text { not }\end{array}$ & $\begin{array}{l}229 \\
632\end{array}$ & $\begin{array}{c}38 \\
146\end{array}$ & $\begin{array}{c}44 \\
122\end{array}$ & $\begin{array}{l}29 \\
86\end{array}$ & 0.409 \\
\hline $\begin{array}{l}\text { Menarche } \\
\text { yes } \\
\text { not }\end{array}$ & $\begin{array}{l}135 \\
726\end{array}$ & $\begin{array}{c}34 \\
150\end{array}$ & $\begin{array}{c}20 \\
146\end{array}$ & $\begin{array}{c}15 \\
100\end{array}$ & 0.346 \\
\hline $\begin{array}{l}\text { Late pregnancy } \\
\text { yes } \\
\text { not }\end{array}$ & $\begin{array}{l}163 \\
698\end{array}$ & $\begin{array}{c}30 \\
154\end{array}$ & $\begin{array}{c}22 \\
144\end{array}$ & $\begin{array}{l}19 \\
96\end{array}$ & 0.319 \\
\hline $\begin{array}{l}\text { Nulligravida } \\
\text { yes } \\
\text { not }\end{array}$ & $\begin{array}{c}97 \\
764\end{array}$ & $\begin{array}{c}21 \\
163\end{array}$ & $\begin{array}{c}11 \\
155\end{array}$ & $\begin{array}{c}15 \\
100\end{array}$ & 0.279 \\
\hline $\begin{array}{l}\text { Oral contraceptive } \\
\text { yes } \\
\text { not }\end{array}$ & $\begin{array}{l}144 \\
717\end{array}$ & $\begin{array}{c}32 \\
152\end{array}$ & $\begin{array}{c}21 \\
145\end{array}$ & $\begin{array}{c}9 \\
106\end{array}$ & $0.050^{*}$ \\
\hline
\end{tabular}

${ }^{*} p \leq 0.05$ was considered as statistically significant

$\mathrm{BC}$ is a public health problem because it is the main cause of death by malignant tumours in women of reproductive age [1]. In this study, we observed that BC was often detected before of 50 years of age, similar to what has been reported by other authors in the Mexican population [15, 16]. This observation confirms that this pathology is detected in Mexican women a decade before the normal age of onset in other countries $[17,18]$. This study also shows the importance of using biological markers to classify pathologies and to make decisions when treating patients. In this context, this study shows, using an analysis of ER, $\mathrm{PR}$, and Her-2/Neu immunoreactivity in tumour biopsies, that Luminal $A$ is the most common breast cancer subtype in our study population, followed by Basal-like, Luminal B, and HER2/Neu as the less common. Although these data show that $77.5 \%$ of patients (classified as luminal A and B) can be treated with ER inhibitors (tamoxifen) or aromatase inhibitors, the association established between these subtypes of tumours and unfavourable characteristics indicate that the late detection of these pathologies in our population is an important factor that probably reduces the success of treatments for this disease.

Basal-like and HER2/Neu breast cancer subtypes have higher mortality rates than the other subtypes in this study and were associated with unfavourable tumour characteristics, suggesting that the high mortality rate for these tumour types could also be related to late diagnosis.

Several studies have reported that ovarian hormones (oestrogens) and reproductive patterns play an important role in the development of breast cancer [19, 20]. However, our study showed no association between breast cancer subtypes and risk factors that have been described in other populations [21], with the exception of the use of oral contraceptives (Table 4). These findings suggest that the association between menstrual and reproductive factors with the development of breast cancer may differ in our study population and that these risk factors do not contribute to the incidence and mortality rate of this pathology in the study population.

In this study, we used a classification system based on the immunohistochemical detection of biological markers (ER, PR, and HER2/Neu). While the use of these biomarkers plays an important role in diagnostic and clinical practice and the guidance of endocrine therapy, very few studies have been reported in our study population. The tumour classifications identified in this study were comparable to studies performed in other countries [22, 23]. However, our data show that the use of these biomarkers allows a definition of the type of breast cancer, which may be useful

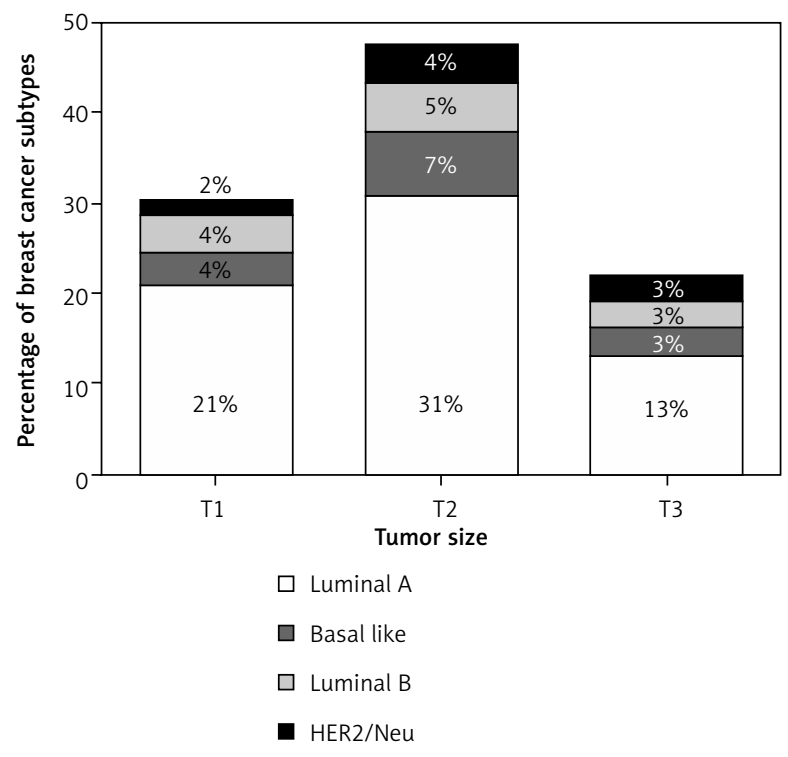

Fig. 1. Distribution of breast cancer subtypes by tumor size 
when selecting the best treatment or when establishing which patients have a higher risk of secondary effects from cytotoxic treatments.

In conclusion, this study describes the subtypes of breast cancer most frequently detected in Mexican women and establishes an association in this population between breast cancer and biological parameters and hormonal state. This classification provides a system for defining breast cancer and supports the use of these biomarkers in the determination of diagnosis and prognosis in these patients.

The authors declare no conflict of interest.

\section{References}

1. Knaul FM, Lopez Carrillo L, Lazcano Ponce E, Gomez Dantes H, Romieu I, Torres G. Breast cancer: a challenge for society and health systems. Salud Publica Mex 2009; 51 Suppl 2: s138-40.

2. Blows FM, Driver KE, Schmidt MK, et al. Subtyping of breast cancer by immunohistochemistry to investigate a relationship between subtype and short and long term survival: a collaborative analysis of data for 10,159 cases from 12 studies. PLoS Med 2010; 7: e1000279.

3. Cheang MC, Chia SK, Voduc D, et al. Ki67 index, HER2 status, and prognosis of patients with luminal B breast cancer. J Natl Cancer Inst 2009; 101: 736-50.

4. Hugh J, Hanson J, Cheang MC, et al. Breast cancer subtypes and response to docetaxel in node-positive breast cancer: use of an immunohistochemical definition in the BCIRG 001 trial. J Clin Oncol 2009; 27: 1168-76.

5. Nielsen TO, Hsu FD, Jensen K, et al. Immunohistochemical and clinical characterization of the basal-like subtype of invasive breast carcinoma. Clin Cancer Res 2004; 10: 5367-74.

6. Goldhirsch A, Ingle JN, Gelber RD, Coates AS, Thurlimann B, Senn HJ. Thresholds for therapies: highlights of the St Gallen International Expert Consensus on the primary therapy of early breast cancer 2009. Ann Oncol 2009; 20: 1319-29.

7. Hortobagyi GN. Treatment of breast cancer. N Engl J Med 1998; 339: 974-84.

8. Bertucci F, Finetti P, Birnbaum D. Basal breast cancer: a complex and deadly molecular subtype. Curr Mol Med 2012; 12: 96-110.

9. Bertucci F, Finetti P, Cervera N, Maraninchi D, Viens P, Birnbaum D. Gene expression profiling and clinical outcome in breast cancer. Omics 2006; 10: 429-43.

10. Cava C, Bertoli G, Ripamonti M, Mauri G, Zoppis I, Rosa PA, Gilardi MC, Castiglioni I. Integration of mRNA Expression Profile, Copy Number Alterations, and microRNA Expression Levels in Breast Cancer to Improve Grade Definition. PloS One 2014; 9: e97681.

11. Sotiriou C, Piccart MJ. Taking gene-expression profiling to the clinic: when will molecular signatures become relevant to patient care? Nat Rev Cancer 2007; 7: 545-53.

12. Gomez P, Rivadeneyra J, Rabago M, Guzman-Patraca C. Estrogen receptors in human breast cancer in Mexican patients. Arch Invest Med (Mex) 1980; 11: 303-13.

13. Martinez ME, Wertheim BC, Natarajan L, et al. Reproductive factors, heterogeneity, and breast tumor subtypes in women of mexican descent. Cancer Epidemiol Biomarkers Prev 2013; 22: 1853-61.

14. Porter P. "Westernizing" women's risks? Breast cancer in lower-income countries. N Engl J Med 2008; 358: 213-6.

15. Calderon-Garciduenas AL, Sanabria-Mondragon M, Hernandez-Beltran L, Lopez-Amador N, Cerda-Flores RM. Mammographic breast density patterns in asymptomatic mexican women. Radiol Res Pract 2012; 2012: 127485.
16. Rodriguez-Cuevas S, Macias CG, Franceschi D, Labastida S. Breast carcinoma presents a decade earlier in Mexican women than in women in the United States or European countries. Cancer 2001; 91: 863-8.

17. Bray F, McCarron P, Parkin DM. The changing global patterns of female breast cancer incidence and mortality. Breast Cancer Res 2004; 6: 229-39.

18. Olsen AH, Bihrmann K, Jensen MB, Vejborg I, Lynge E. Breast density and outcome of mammography screening: a cohort study. $\mathrm{Br}$ J Cancer 2009; 100: 1205-8.

19. Green J, Cairns BJ, Casabonne D, Wright FL, Reeves G, Beral V. Height and cancer incidence in the Million Women Study: prospective cohort, and meta-analysis of prospective studies of height and total cancer risk. Lancet Oncol 2011; 12: 785-94.

20. Ogawa Y, Hai E, Matsumoto K, et al. Androgen receptor expression in breast cancer: relationship with clinicopathological factors and biomarkers. Int J Clin Oncol 2008; 13: 431-5.

21. Elebro K, Butt S, Dorkhan M, Jernstrom H, Borgquist S. Age at first childbirth and oral contraceptive use are associated with risk of androgen receptor-negative breast cancer: the Malmo Diet and Cancer Cohort. Cancer Causes Control 2014; 25: 945-57.

22. Irigoyen MA, Garcia FV, Iturriagagoitia AC, Beroiz BI, Martinez MS, Grima FG. Molecular subtypes of breast cancer: prognostic implications and clinical and immunohistochemical characteristics. An Sist Sanit Navar 2011; 34: 219-33.

23. Mehdi I, Monem AA, Al Bahrani B, Ramadhan FA. Breast cancer molecular subtypes in Oman: correlation with age, histology, and stage distribution - analysis of 542 cases. Gulf J Oncolog 2014; 1: 38-48.

\section{Address for correspondence}

Jose R. Garcia Sanchez

Escuela Superior de Medicina del Instituto Politecnico Nacional jrgarcias@ipn.mx

Submitted: 15.07 .2015

Accepted: $\quad 15.10 .2015$ 